\title{
Pengaruh Penguasaan Konsep Aljabar dan Adversity Quetiont Terhadap Kemampuan Pemecahan Masalah Pada Siswa Kelas XI SMK Muhammadiyah Ambon
}

\author{
Ayu Lestari ${ }^{1 *}$, Ajeng Gelora Mastuti ${ }^{2}$, Fahruh Juhaevah ${ }^{3}$ \\ 1Pendidikan Matematika, IAIN Ambon, Ambon, Indonesia; \\ * ayyulestari021197@gmail.com \\ 2Pendidikan Matematika, IAIN Ambon, Ambon, Indonesia; \\ ajeng.gelora.mastuti@iainambon.ac.id \\ 3Pendidikan Matematika, IAIN Ambon, Ambon, Indonesia; \\ fahruh.juhaevah@iainambon.ac.id
}

\section{Abstrak.}

Penelitian ini bertujuan untuk mengetahui bagaimanakah pengaruh penguasaan konsep aljabar dan adversity quotient terhadap kemampuan pemecahan masalah pada siswa kelas XI SMK Muhammadiyah Ambon. Jenis penelitian yang digunakan adalah penelitian deskriptif kuantitatif, metode penelitian yang diterapkan adalah $e x$ post facto. Subjek dalam penelitian ini adalah siswa kelas XI SMK Muhammadiyah Ambon yang berjumlah 25 orang siswa. Hasil penelitian menunjukan bahwa, ada pengaruh yang signifikan penguasaan aljabar dan adversity question terhadap pemecahan masalah pada materi persamaan kuadrat siswa kelas XI SMK Muhammadiyah Ambon yang ditunjukkan dengan hasil analisis uji-t antara variabel Penguasaan Konsep Aljabar dan Adversity Question terhadap variabel Kemampuan Pemecahan Masalah di peroleh nilai sig. $0.01<0,05$, dan nilai $t$ hitung $5.648>$ 1.319.Dengan demikian Besar pengaruh penguasaan aljabar dan adversity question terhadap pemecahan masalah pada materi persamaan kuadrat siswa kelas XI SMK Muhammadiyah Ambon diperoleh sebesar 34\% sedangkan 66\% dipengaruhi variabel lain selain variabel Penguasaan Aljabar dan Adversity Question.

Kata Kunci: Penguasaan Aljabar, Adversity Question dan Pemecahan Masalah

\begin{abstract}
.
This study aims to determine how the influence of mastery of algebraic concepts and adversity quotient on problem solving abilities in class XI students of SMK Muhammadiyah Ambon. The type of research used is descriptive quantitative research, the research method applied is ex post facto. The subjects in this study were students of class XI SMK Muhammadiyah Ambon, totaling 25 students. The results showed that, there was a significant effect of mastery of algebra and adversity question on problem solving on the quadratic equation material for class XI students of SMK Muhammadiyah Ambon as indicated by the results of t-test analysis between the variables of Mastery of Algebraic Concepts and Adversity Questions on the variable of Problem Solving Ability obtained. sig value. $0.01<0.05$, and the value of $t$
\end{abstract}


arithmetic is 5,648 $>1.319$. Thus, the influence of mastery of algebra and adversity question on problem solving in the quadratic equation material for class XI students of SMK Muhammadiyah Ambon is 34\% while $66 \%$ is influenced by other variables besides the variable of Algebra Mastery. and Adversity Questions.

Keywords: Algebra Mastery, Adversity Question and Problem Solving

\section{Pendahuluan}

Penelitian tentang pemecahan masalah dan adversity question telah dilakukan oleh beberapa peneliti, diantaranya Nova Nurhanifah (2019) yang berjudul Analisis Terhadap Kemampuan Pemecahan Masalah Matematis Siswa SMP Berdasarkan Adversity Quotient (AQ) pada salah satu SMP di Kabupaten Garut yang Hasil penelitian menunjukkan bahwa siswa quitter mengalami kesulitan pada tahap memahami masalah dan membuat rencana strategi pemecahan masalah. Siswa camper mengalami kesulitan pada proses melaksanakan strategi penyelesaian masalah. Sedangkan siswa climber tidak mengalami kesulitan apapun dalam menyelesaikan soal pemecahan masalah matematis. Wahyu Hidayat dan Ratna Sariningsih tahun 2018 dengan judul "Kemampuan Pemecahan Masalah Matematis dan Adversity Quotient Siswa SMP Melalui Pembelajaran Open Ended". Hasil penelitian menunjukan bahwa (1) Kemampuan pemecahan masalah matematika siswa SMP pada materi keliling dan luas persegi panjang dengan pembelajaran open ended mencapai ketuntasan belajar; (2) Siswa AQ quitters dalam memecahkan masalah mampu memahami masalah dengan menuliskan apa yang diketahui dan apa yang ditanyakan dan menjelaskan masalah dengan kalimat sendiri; (3) Siswa AQ campers dalam memecahkan masalah mampu melaksanakan tiga tahapan Polya yaitu memahami masalah, merencanakan pemecahan, dan melaksanakan rencana; Siswa AQ climbers dalam memecahkan masalah mampu melaksanakan keempat tahap Polya yaitu mampu memahami masalah, merencanakan pemecahan masalah, menyelesaikan masalah melalui strategi pemecahan masalah, serta memeriksa kembali hasil dan proses dan menyimpulkan hasil penyelesaian. yang membedakan penelitian terdahulu dengan penelitian ini ialah tentang Penguasaan Konsep Aljabar dan Adversity Quetiont Terhadap Kemampuan Pemecahan Masalah sehingga penting untuk diteliti.

\section{Metode}

Jenis penelitian yang digunakan adalah penelitian deskriptif kuantitatif, yaitu penelitian yang dimaksudkan untuk mengumpulkan informasi-informasi berupa angka sebagai alat penemuan yang datanya berupa bilangan. ${ }^{1}$ Metode 
penelitian yang diterapkan dalam penelitian ini adalah ex post facto. Subjek dalam penelitian ini adalah siswa kelas XI SMK Muhammadiyah Ambon dengan jumlah siswa sebanyak 25 siswa. Jenis data yaitu data kauntitatif diperoleh melalui hasil tes dan kuesioner. Instrumen dalam penelitian berupa soal tes awal digunakan untuk mengukur penguasaan konsep aljabar berupa soal uraian berjumlah 3 butir soal, soal tes akhir digunakan untuk mengukur kemampua pemecahan masalah berupa soal uraian berjumlah 2 butir soal dan kuesioner digunakan untuk mengkur adversity quotient yang terdiri dari 33 pernyataan. Semua instrumen yang digunakan sudah valid karena telah divalidasi oleh validator yang berkompeten. Penelitian ini akan mendeskripsikan pengaruh penguasaan konsep aljabar dan adversity quotient terhadap kemampuan pemecahan masalah.

\section{Hasil dan Pembahasan}

Penelitian ini dilaksanakan pada tanggal 25 Februari sampai tanggal 25 Maret 2021. Selanjutnya proses pembelajaran dilaksanakan pada tanggal 10 Maret sampai 16 Maret 2021, sebanyak tiga kali pertemuan pada kelas yang diteliti untuk mengetahui pengaruh penguasaan konsep aljabar dan adversity question terhadap kemampuan pemecahan masalah pada materi persamaan kuadrat siswa kelas XI SMK Muhammadiyah Ambon, dengan sampel sebanyak 25 orang siswa. Data penelitian ini diambil menggunakan tes penguasaan konsep aljabar $\left(\mathrm{X}_{1}\right)$ kuesioner adversity question $\left(\mathrm{X}_{2}\right)$ dan soal tes kemampuan pemecahan masalah $(\mathrm{Y})$. Adapun analisis penelitian sebagai berikut:

\section{Uji Linieritas}

Uji Linieritas varians data tentang Penguasaan Aljabar (X1) dan Adversity Question (X2) terhadap Pemecahan Masalah (Y) pada penelitian ini menggunakan dengan bantuan SPSS version 25 for Windows dan diperoleh berikut ini;

Hasil Uji Linieritas Varians Data Penguasaan Aljabar (X1) Terhadap Pemecahan Masalah $(\mathrm{Y})$ diperoleh nilai sig. $=0,988$. Sehingga diperoleh nilai sig. $=0,988>a=0,05$ artinya varians data masing-masing variabel berasal dari sampel yang linier.Hasil Uji Linieritas Varians Data Adversity Question (X2) terhadap Pemecahan Masalah (Y) diperoleh nilai sig. 0,228. Sehingga diperoleh nilai sig. 0,228 $>a 0,05$ artinya varians data masing-masing variabel berasal dari sampel yang linier. 


\section{Analisis Regresi Berganda}

Analisis Regresi Berganda Variabel Penguasaan Aljabar (X1) dan Adversity Question (X2) terhadap Pemecahan Masalah (Y). Persamaan regresi yang diperoleh $Y=10.801-0.824 X_{1}+1.653 X_{2}$. Model persamaan regresi tersebut mengandung arti bahwa:

1) Konstanta sebesar 10.801 menyatakan jika variabel Penguasaan Aljabar $\left(X_{1}\right)$ dan adversity question $\left(X_{2}\right)$ dianggap konstan, maka rata-rata pemecahan masalah siswa Kelas XI SMK Muhammadiyah Ambon sebesar 10.801 .

2) Koefisien Penguasaan Aljabar $\left(X_{1}\right)$ sebesar -0.824 berarti bahwa setiap terjadi kenaikan 1 skor variabel Penguasaan Aljabar belajar, maka akan diikuti dengan penurunan kemampuan pemecahan masalah matematika sebesar 0.824 dengan asumsi variabel lain dalam keadaan tetap.

3) Koefisien Adversity question $\left(X_{2}\right)$ sebesar 1.653 berarti bahwa setiap terjadi kenaikan 1 skor variabel adversity question, maka akan diikuti dengan kenaikan prestasi belajar matematika sebesar 1.653 dengan asumsi variabel lain dalam keadaan tetap.

\section{Uji Hipotesis}

Uji Hipotesis pada dasarnya menunjukkan apakah kedua variabel bebas Penguasaan Aljabar ( $\left.\mathrm{X}_{1}\right)$ dan Adversity Question $\left(\mathrm{X}_{2}\right)$ yang dimasukkan dalam model mempunyai pengaruh secara bersama-sama terhadap variabel dependen Kemampuan Pemecahan Masalah (Y).

Uji Hipotsis (Uji t). dujikan untuk hipotesis ke-tiga (H3) yaitu " apakah ada pengaruh penguasaan aljabar dan adversity question terhadap hasil belajar matematika siswa kelas XI SMK Muhammadiyah Ambon. Dengan ketentuan:

- Jika nilai sig <0,05 atau $t$ hitung $>t$ tabel maka terdapat pengaruh variabel Penguasaan Aljabar $\left(X_{1}\right)$ dan Adversity Question $\left(X_{2}\right)$ secara simultan terhadap pemecahan masalah (Y). Jika nilai sig $>0,05$ atau $t$ hitung $<\mathrm{t}$ tabel maka tidak terdapat pengaruh variabel Penguasaan Aljabar $\left(X_{1}\right)$ dan Adversity Question $\left(X_{2}\right)$ secara simultan terhadap pemecahan masalah (Y). Lebih jelasnya hasil uji $t$ menggunakan bantuan SPSS Version 25 For Windows.

- Nilai sig untuk pengaruh variabel Penguasaan Aljabar ( $\left.X_{1}\right)$ dan Adversity Question (X2) terhadap Pemecahan Masalah (Y) adalah sebesar $0.01<0,05$, dan nilai t hitung $5.678>1.319$, sehingga dapat disimpulkan bahwa (H1) diterima yang berarti terdapat pengaruh Penguasaan

Copyright (C) 2021

Buana Matematika:

Jurnal Ilmiah Matematika dan Pendidikan Matematika 
Aljabar dan Adversity Question terhadap kemampuan pemecahan masalah.

\section{Koefisien Determinasi}

Hasil Koefisien Determinasi Variabel penguasaan Aljabar ( $\left.X_{1}\right)$ AdversityQuestion $\left(\mathrm{X}_{2}\right)$ Terhadap Kemampuan Pemecahan Masalah (Y) diperoleh bahwa besarnya pengaruh variabel penguasaan Aljabar dan Adversity Question Terhadap Kemampuan Pemecahan Masalah, dapat diketahui dari besarnya koefisien determinasi (R-Square) yaitu 0,340. Dengan demikian, besarnya pengaruh penguasaan Aljabar dan Adversity Question Terhadap Kemampuan Pemecahan Masalah adalah 34\%, sedangkan 66\% dipengaruhi variabel lain selain variabel Penguasaan Aljabar dan Adversity Question.

\section{Pembahasan}

Dalam pelaksanaan penelitian ini peneliti melaksanakan proses pembelajaran sebanyak 2 kali di kelas XI SMK Muhammadiyah Ambon yang berjumlah 25 siswa. Kemudian data yang diperoleh dianalisis menggunakan uji-t. Sebelum dianalisis menggunakan uji-t data diuji dengan menggunakan uji validitas, uji normalitas dan analisis persamaan regresi linier berganda dengan menggunakan bantuan SPSS Vertion 25.

Berdasarkan hasil uji validitas dari 42 item kuesioner, terdapat 33 item yang valid dan 9 item tidak valid sehingga tidak digunakan dalam analisis.

Berdasarkan Tabel 4.13 ANOVA, diperoleh nilai t hitung $=5,678$ dengan taraf nilai Sig $=0,010$. Untuk menguji hipotesis yang diajukan diterima atau ditolak yaitu dengan melihat nilai $\mathrm{F}$ dan taraf nilai signifikansi. Adapun hipotesis yang diajukan adalah sebagai berikut:

H0 : tidak ada pengaruh konsep aljabar dan Adversity Quotient (AQ) terhadap kemampuan pemecahan masalah

H1 : ada pengaruh konsep aljabar dan Adversity Quotient (AQ) terhadap kemampuan pemecahan masalah

Dengan ketentuan penerimaan atau penolakan terjadi: Jika nilai $t$ hitung $t$ tabel $d a n$ taraf nilai Sig 0,05, maka H0 ditolak. Jika nilai $t$ hitung $t$ tabel dan taraf nilai Sig 0,05, maka H0 diterima.

Sebelum melihat nilai $t$ tabel, maka terlebih dahulu harus menentukan derajat kebebasan pembilang (df) dan derajat kebebasan penyebut (db). Pada keseluruhan sampel yang diteliti $(\mathrm{N})$ dengan rumus $\mathrm{df}=\mathrm{m}$ (jumlah prediktor) Copyright $@ 2021$

Ouana Matematika :

Jurnal Ilmiah Matematika dan Pendidikan Matematika 
dan $\mathrm{db}=\mathrm{N}-\mathrm{m}-1$. Dalam penelitian ini, jumlah prediktor ada $2(\mathrm{X} 1$ dan $\mathrm{X} 2)$ dan jumlah sampel yang digunakan adalah 25 siswa, maka $\mathrm{df}=2 \mathrm{dan} \mathrm{db}=25$ $-2-1=22$ pada taraf signifikansi 5\%. Maka ditemukan nilai $\mathrm{t}$ tabel $=1,319$. Karena nilai $\mathrm{t}$ hitung $=5,678>\mathrm{t}$ tabel $=1,319$ dan taraf nilai $\mathrm{Sig}=0,01$ sehingga dapat disimpulkan bahwa H0 ditolak, artinya ada pengaruh penguasaan aljabar dan Adversity Quotient (AQ) terhadap kemampuan pemecahan masalah

Kemampuan pemecahan masalah dipengaruhi oleh Penguasaan aljabar dan Adversity Quotient (AQ) siswa secara bersama-sama. Maksudnya jika penguasaan aljabar siswa tinggi dan $A Q$ siswa tinggi maka kemampuan pemecahan masalah juga tinggi, dan sebaliknya jika penguasaan aljabar siswa rendah dan $\mathrm{AQ}$ siswa rendah maka kemampuan pemecahan masalah juga rendah. Begitu juga apa yang terjadi dilapangan, di sekolah siswa yang memiliki penguasaan aljabar tinggi dan AQ tinggi pula kemampuan pemecahan juga tinggi. Hal ini juga didukung oleh teori Myers (1996) yang mengatakan bahwa penguasaan konsep aljabar telah dianggap sebagai suatu norma yang menentukan perkembangan kemampuan dan pencapaian optimal kemampuan pemecahan masalah anak disekolah. Karena penguasaa konsep aljabar merupakan bekal potensial yang akan memudahkan dalam belajar dan pada gilirannya akan menghasilkan prestasi belajar yang optimal. ${ }^{2}$ Begitu juga dari hasil penelitian yang dilakukan oleh Afif Eka Alikfiyono Putri dalam skripsinya yang berjudul Pengaruh Penguasaan aljabar dan Kreativitas Siswa Terhadap Kemampuan pemecahan masalah Kelas VII SMPN 3 Kedungwaru yaitu ada pengaruh Penguasaan aljabar dan kreativitas siswa terhadap kemampuan pemecahan masalah.

Berdasarkan Tabel 4.14 Model Summary, dapat dijelaskan bahwa variabel Penguasaan aljabar dan Adversity Quotient (AQ) secara bersama-sama mempengaruhi variabel kemampuan pemecahan masalah. Pada tabel tersebut diperoleh nilai Adjusted R Square adalah 0,340 yang artinya 34\% kemampuan pemecahan masalah dipengaruhi oleh Penguasaan aljabar dan Adversity Quotient (AQ) secara bersama-sama.

Berdasarkan Tabel 4.12 Coefficient, diperoleh persamaan regresi linier ganda $\mathrm{Y}=10.801-0,824 \mathrm{X} 1+1,653 \mathrm{X} 2$, yang berarti:

1) Rata-rata skor kemampuan pemecahan masalah $(Y)$ akan mengalami perubahan sebesar $-0,824$ untuk setiap unit perubahan yang terjadi pada skor Penguasaan aljabar (X1). Maksudnya jika skor Penguasaan aljabar naik satu 
skor maka kemampuan pemecahan masalah akan mengalami kenaikan sebesar 0,824. Dan sebaliknya, jika skor Penguasaan aljabar turun satu skor maka kemampuan pemecahan masalah akan mengalami penurunan sebesar 0,824 dengan anggapan (X2) tetap.

2) Rata-rata skor kemampuan pemecahan masalah (Y) akan mengalami perubahan sebesar 1,653 untuk setiap unit perubahan yang terjadi pada skor Adversity Quotient (AQ) (X2). Maksudnya jika skor Adversity Quotient (AQ) naik satu skor maka kemampuan pemecahan masalah akan mengalami kenaikan sebesar 1,653. Dan sebaliknya, jika skor Adversity Quotient (AQ) turun satu skor maka kemampuan pemecahan masalah akan mengalami penurunan sebesar 1,653 dengan anggapan (X1) tetap

Hasil penelitian yang telah dilakukan di SMK Muhammadiyah Ambon membuktikan bahwa penguasaan aljabar dan adversity question berpengaruh signifikan terhadap kemampuan pemecahan masalah. Hasil penelitian ini didukung oleh hasil penelitian yang dilakukan oleh Wahyu Hidayat dan Ratna Sariningsih tahun 2018 dengan judul "Kemampuan Pemecahan Masalah Matematis dan Adversity Quotient Siswa SMP Melalui Pembelajaran Open Ended". Hasil penelitian menunjukan bahwa (1) Kemampuan pemecahan masalah matematika siswa SMP pada materi keliling dan luas persegi panjang dengan pembelajaran open ended mencapai ketuntasan belajar; (2) Siswa AQ quitters dalam memecahkan masalah mampu memahami masalah dengan menuliskan apa yang diketahui dan apa yang ditanyakan dan menjelaskan masalah dengan kalimat sendiri; (3) Siswa AQ campers dalam memecahkan masalah mampu melaksanakan tiga tahapan Polya yaitu memahami masalah, merencanakan pemecahan, dan melaksanakan rencana; Siswa AQ climbers dalam memecahkan masalah mampu melaksanakan keempat tahap Polya yaitu mampu memahami masalah, merencanakan pemecahan masalah, menyelesaikan masalah melalui strategi pemecahan masalah, serta memeriksa kembali hasil dan proses dan menyimpulkan hasil penyelesaian. ${ }^{3}$

Hasil penelitian juga sejalan dengan penelitian yang dilakukan oleh Merianah Dengan judul Pengaruh Kecerdasan Emosional dan Adversity Quotient terhadap Kemampuan Pemecahan Masalah Matematika Siswa Sdit Penguasaan Aljabarra'1 Kota Bengkulu, Hasil penelitian menunjukkan ada pengaruh langsung positif secara signifikan antara kecerdasan emosi, 
Adversity quotient, kecerdasan emosional, serta kecerdasan emosi terhadap Adversity quotient.

Penelitian oleh Rina Faizatul Imroah tentang Pengaruh Penguasaan aljabar dan Adversity Quotient (AQ) terhadap Kemampuan pemecahan masalah Kelas X MAN Trenggalek, hasil penelitian diperoleh Ada pengaruh Penguasaan aljabar dan Adversity Quotient (AQ) terhadap kemampuan pemecahan masalah kelas X MAN Trenggalek tahun pelajaran 2016/2017. Hal ini ditunjukkan oleh nilai Fhitung $=18,463>$ Ftabel $=3,33$ dan taraf nilai Sig = 0,000 0,05, maka H0 ditolak dan H1 diterima. Hal ini berarti Penguasaan aljabar dan Adversity Quotient (AQ) secara bersama-sama memberikan pengaruh terhadap kemampuan pemecahan masalah kelas X MIA 2 MAN Trenggalek. 2. Besar pengaruh Penguasaan aljabar dan Adversity Quotient (AQ) terhadap kemampuan pemecahan masalah adalah 53\% termasuk dalam kriteria sedang.

Jadi semakin baik penguasaan aljabar dan adversity question siswa maka akan berpengaruh terhadap pemecahan masalah siswa, sebaliknya jika penguasaan konsep aljabar dan adversity question siswa yang kurang baik maka akan berpengaruh kurang baik terhadap kemampuan pemecahan masalah siswa.

\section{Kesimpulan}

Berdasarkan hasil penelitian dan pembahasan yang telah diuraikan pada bab sebelumnya, maka dapat disimpulkan antara lain, ada pengaruh yang signifikan penguasaan aljabar dan adversity question terhadap pemecahan masalah pada materi persamaan kuadrat siswa kelas XI SMK Muhammadiyah Ambon yang ditunjukkan dengan hasil analisis uji hipotesis menggunakan Uji Ketergantungan (uji-t) antara variabel $\mathrm{X}_{1}$ (Penguasaan Aljabar), $\mathrm{X}_{2}$ (Adversity Question) dan variabel Y (Kemampuan Pemecahan Masalah) di peroleh nilai sig. $0.01<0,05$, dan nilai t hitung $5.648>1.319$ artinya hipotesis $\mathrm{H}_{1}$ diterima. Besar pengaruh yang penguasaan aljabar dan adversity question terhadap pemecahan masalah pada materi persamaan kuadrat siswa kelas XI SMK Muhammadiyah Ambon diperoleh sebesar 34\% sedangkan 66\% dipengaruhi variabel lain selain variabel Penguasaan Aljabar dan Adversity Question.

\section{Daftar Pustaka}

Imroah, r. F. (2018). Pengaruh intelligence quotient (iq) dan adversity quotient (aq) terhadap hasil belajar matematika siswa kelas $\mathrm{x}$ man trenggalek tahun pelajaran 2016/2017 
Gusniwati, m. (2021). Pengaruh adversity question dan kecerdasan emosional terhadap penguasaan konsep matematika. Jurnal pionir, 7(1).

Chasanah, e. N. (2017). Pengaruh penguasaan materi operasi aljabar terhadap kemampuan menyelesaikan soal-soal persamaan kuadrat kelas viii mtsn 2 kota blitar tahun pelajaran 2016/2017. hlm.10.

Setiyohadi, I. (2015). Pengaruh Penguasaan Materi Operasi Bentuk Aljabar terhadap Kemampuan Menyelesaikan Soal-soal Sistem Persamaan Linear Dua Variabel (SPLDV) pada Siswa Kelas VIII SMP Negeri 6 Purworejo Tahun Pelajaran 2014/2015 (Doctoral dissertation, Pendidikan Matematika-FKIP). hlm. 12.

Merianah, M. (2019). Pengaruh Kecerdasan Emosional dan Adversity Quotient terhadap Kemampuan Pemecahan Masalah Matematika Siswa SDIT IQRA'1 Kota Bengkulu. Jurnal Pendidikan Matematika Raflesia, 4(1), 29-35.

Sugiyono, Metode Penelitian Pendidikan (Pendekatan Kuantitatif, Kualitatif, dan R \& D), (Bandung: Alfabeta, 2010), hlm 257.

Hidayat, W., \& Sariningsih, R. (2018). Kemampuan pemecahan masalah matematis dan adversity quotient siswa SMP melalui pembelajaran open ended. JNPM (Jurnal Nasional Pendidikan Matematika), 2(1), hlm. 109.

Saifuddin Azwar, Pengantar Psikologi Inteligensi, (Yogyakarta: Pustaka Pelajar, 2015), hlm 163

Suharsimi Arikunto, Manajemen Penelitian, (Cet. IV, Jakarta: Rineka Cipta, 1998), hlm. 309.

Chasanah, e. N. (2017). Pengaruh penguasaan materi operasi aljabar terhadap kemampuan menyelesaikan soal-soal persamaan kuadrat kelas viii mtsn 2 kota blitar tahun pelajaran 2016/2017

Hidayat, W., \& Sariningsih, R. (2018). Kemampuan pemecahan masalah matematis dan adversity quotient siswa SMP melalui pembelajaran open ended. JNPM (Jurnal Nasional Pendidikan Matematika), 2(1)

\section{Riwayat Hidup Penulis}

\section{Ayu Lestari}

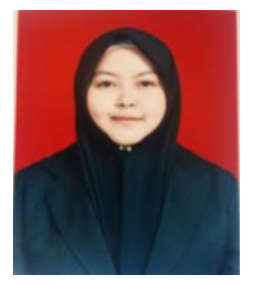

Lahir di Blora, 2 November 1997. Studi S1 bidang Pendidikan Matematika IAIN Ambon, Ambon, lulus tahun 2021 


\section{Ajeng Gelora Mastuti}

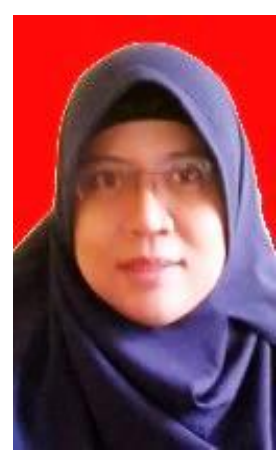

Lahir di Kediri, 6 Mei 1984. Ketua Jurusan, Pendidikan Matematika IAIN Ambon. Studi S1 Bidang Pendidikan Matematika Universitas Negeri Surabaya, Surabaya, lulus tahun 2006; Studi S2 Bidang Pendidikan Matematika Universitas Negeri Surabaya, Surabaya, lulus tahun 2009; dan Studi S1 Bidang Pendidikan Matematika Universitas Negeri Malang, Malang, lulus tahun 2017. Aktif Meneliti, membuat buku, artikel, Kegiatan Konfrensi/ Seminar/ Lokakarya/ Simposium (Kegiatan Webinar Nasional/ Internasional).

\section{Fahruh Juhaevah}

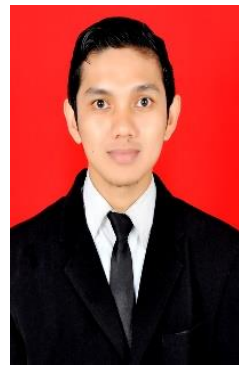

Lahir di Bulukumba , 29 Maret 1992. Aktif mengajar di Jurusan Pendidikan Matematika IAIN Ambon . Studi S1 Bidang Pendidikan Matematika Universitas Negeri Makassar, Makassar, lulus tahun 2014; dan S2 Bidang Pendidikan Matematika Universitas Negeri Surabaya, Surabaya, lulus tahun 2016. Meneliti serta editor di Jurnal Matematika, pembelajaran dan JTMT. 